\title{
Psychosocial Work Factors as A Predictor of Employee Health and Performance Among Public Hospitals in Rivers State
}

\author{
Emmanuel Aziegbe Akhigbe ${ }^{1}$ and Taiye Eletu Issa ${ }^{2}$ \\ ${ }^{1,2}$ Department of Management, University of Port Harcourt. Port Harcourt, Nigeria \\ DOI - http://doi.org/10.37502/IJSMR.2022.5203
}

\begin{abstract}
This study examined the link between psychosocial work factors (PWF), employee health and performance among the employees working in the public hospitals in Rivers State. A sample size of 97 workers was drawn from a population of 100 and a cross-sectional survey was utilized. Copies of the questionnaire were distributed to collect data that was analyzed using the Spearman Rank Order Correlation Coefficient. The results revealed a significant relationship between psychosocial work factors (leadership quality, work-family conflict and job demand) and employee health and performance. However, our study found that workfamily conflict (WFC) and employee performance appeared to have a stronger link. It was concluded that psychosocial work factors positively affect employees' performance and health at work. The study recommends that the public hospitals, which want to improve their employees' performance, ensure that employees' family conflict is adequately managed to avoid its clash with work duties or responsibilities.
\end{abstract}

Keywords: Psychosocial Work Factors, Employee Health, Employee Performance, Leadership Quality, Job Demand, Work-Family Conflict.

\section{Introduction}

Regardless of the philosophy and orientation of any organization, there are significant factors that influences employee behaviour, health and performance levels in the workplace. Psychosocial factors are components that are connected to an employee's psychological and social aspects, and they influence their behaviour and work outcomes. Employee psychosocial work factors such as mental stability and emotional disorder impact employees' performance and health over time (Sharma, Dhar, \& Tyagi, 2016). Similarly, Mwendwa, McAuliffe, Uduma, Masanja, and Mollel (2017) found that how employees relate with a company affects their motivation, inventive attitude, absenteeism, engagement with coworkers and dedication, all of which can have a substantial influence on their performance. The same writers went on to say that employee performance and productivity has become a major source of concern for many businesses. Furthermore, Ramya (2016) asserted that employee performance and health are important to businesses since they influence the desired outcome of the organization. Nguyen, Luan and Khoa (2021) opined that employee performance are essential relevant to the organizational success. Similarly, health organizations' performance is crucial since their 
responsibilities revolve around life and require more attention. For example, an employee suffering from malaria symptoms such as headache and physical weakness may performance poorly at that time, but an employee in good health may performance well, implying that performance is linked to how healthy a worker is at the moment. Pfeffer (2010) have stated that employee health is a specific relevant indication of individual or human sustainability. Employee health is important because it affects their psychological, emotional and physical state which thus impacts their outcomes in the organization.

The performance of the individual in the workplace influences their organizational success and boost their fortune (Hermina \& Yosepha, 2019; Kuruppu, Kavirathne \& Karunarathna, 2021). As a result, Okeafor and Alamina (2018) discovered that employees are exposed to a variety of work environments, with psychosocial workplace factors playing a significant role. Job content, organizational structure, and employee competencies, as well as employees' demands, cultural dimension, perceptions and personal experience, and job happiness, are all possible factors. Siegrist (1996) developed "Effort-Reward Imbalance models," from which psychosocial factors such as psychological demands, family work balance, leadership style, coworker support and task reward emerged. Kennedy (2018) also looked at the "assessment of psychosocial risks among workers at the University of Port Harcourt" in a survey of 600 people. The study paid special attention to psychological factors such as workplace bullying, which was one of the most prevalent factors in the study, as well as work stress. In addition, in a sample of 18 officers from Vilnius correlational institution, Baranuaskiene, Dirzyte, and Valaikiene (2010) looked at the relationship of psychosocial work factors to job satisfaction, quality of life, and feeling of harmony among officers. Despite the numerous studies on psychosocial work factor, employee health and performance, there is no clear evidence of how psychosocial work factors in terms of leadership quality, job demand, and family work balance relate to employee health and performance, particularly among public hospital workers in Rivers State. As a result, the current study aims to close these gaps.

\section{Statement of the Problem}

Employee performance is a vital aspect that have been examined by many firms regardless of their industry, particularly in the health sector. This might be due to the fact that medical or health employees are frequently confronted with complicated tasks, since the majority of their occupations include dealing with human life and hence management expectations are high. Employees in the health sector, are constantly exposed to various hazards and this do affect their performance and wellbeing in the organization. The low performance and wellbeing of the employees in the health sector can intensify patient's dissatisfaction and can also increase the death rate. It is thus important to address their psychosocial factors in the organization in order to resolve the issue of wellbeing and performance. Ibrahim, Aziz, Suhaili, Daud, Naing and Rahman (2019) maintained that psychosocial work factor help creates a conducive workplace. Akhigbe and Eketu (2021) reported that withdrawal of employees in health sector will persist continuously if the psychosocial work factor is not well managed. As a result, the current study suggests that suitable and appropriate management tactics might be implemented as a tool to combat employee underperformance and health related challenges. Hence, this work examined how psychosocial work factor such as leadership quality, correct handling of work- 
family conflict, and job demand relates with health and performance among public health employees in Rivers State. .

\section{Objectives of the Study}

The objectives of the study are to examine the relationship between:

i. Leadership quality and employee performance of public hospitals in Rivers State.

ii. Leadership quality and employee health of public hospitals in Rivers State.

iii. Work-family conflict and employee performance of public hospitals in Rivers State

iv. Work-family conflict and employee health of public hospitals in Rivers State

v. Job demand and employee performance of public hospitals in Rivers State.

vi. Job demand and employee health of public hospitals in Rivers State.

\section{Research Questions}

What is the relationship between;

i. Leadership quality and employee performance of public hospitals in Rivers State.?

ii. Leadership quality and employee health of public hospitals in Rivers State.?

iii. Work-family conflict and employee performance of public hospitals in Rivers State.?

iv. Work-family conflict and employee health of public hospitals in Rivers State.?

v. Job demand and employee performance of public hospitals in Rivers State.?

vi. Job demand and employee health of public hospitals in Rivers State.?

\section{Research Hypotheses}

HO1: There is no significant relationship between leadership quality and employee performance of public hospitals in Rivers state.

HO$_{2}$ : There is no significant relationship between leadership quality and employee health of public hospitals in Rivers state.

HO3: There is no significant relationship between work-family conflict and employee performance of public hospitals in Rivers state.

HO4: There is no significant relationship between work-family conflict and employee health of public hospitals in Rivers state.

HOs: There is no significant relationship between job demand and employee performance of public hospitals in Rivers state.

HO6: There is no significant relationship between job demand and employee health of public hospitals in Rivers state.

\section{Review of Related Literature}

This research is based on the Social Identity Theory (SIT), which states that people tend to categorize themselves into several social categories that explain their identities and responsibilities in society. For example, a person may see himself as a valuable employee, a kind husband, a responsible father, or an expert, among other things. Each of these positions makes the individuals engaged with a unique piece of their identity. Some people believe that being a recognized employee is the most essential component of their identity, whilst others 
may derive more joy from their job as a spouse or another social role, which has an impact on their mental state (Lobel, 1991). The social identity theory, which proposes that a person's perception of who they are is founded on their group members, is one of Henri Tajfel's biggest achievements as a Psychologist. In SIT, the group people belong to (social class, family, sports team, religious team, etc.) were a major source of pride and self-esteem (McLeod, 2019). Individuals tend to group themselves and embrace particular viewpoints that suit their selfesteem obtained from group identification. Tajfel and his colleagues proposed social identity theory in social psychology to research (Tajfel, 1978). The idea of social identity explains how people's self-concepts are founded on their participation in groups within society. It also examines how social identity influences people's attitudes and conduct in other areas of life, such as the workplace (Leaper, 2011). Furthermore, social identity theory explains why specific workers (managers, nurses, physicians, instructors, supervisors, and so on) act in certain ways. It describes how psychosocial work factors such as leadership style, work-family conflict, and job demand affect an individual's performance and health. The group one finding his own herself influences their psychosocial state which thus influences their performance and health.

\subsection{Concept of Psychosocial Work Factor (PWF)}

The term "psychosocial factors" refers to the interaction of work content, work structure and management, other organizational and environmental factors, and employee skills and requirements (Fernandes \& PereiraI, 2016). To Ceballos-Vásquez et al. (2015), psychosocial factors include communication between work, workers, the environment, work satisfaction, and organizational frameworks. Psychosocial work factor can be defined as the interaction between the psychological state and social aspect of the employees that affects their satisfaction and performance in the workplace. Furthermore, PWFs are important to employees, particularly those who work in the hospital setting, because they are constantly charged with high responsibility, confronted with unpredictable events such as emergencies, and interact with families, including the task of maintaining family work balance. The authors found various work factors that might contribute to burnout, discontent, and stress, including organizational features, persistent mental demands, and consistent performance concerns. The individual's demands at work in terms of his or her ability to govern activities and skill utilizations are examined and addressed in connection to psychosocial work circumstances (Karasek \& Theorell, 1990). General, regardless of hierarchical level, psychosocial work circumstances are thought to play a substantial effect in employee health. Okeafor and Alamina (2018) further pointed out that psychosocial workplace factors are determined by interactions between many factors, which explains their nature. These factors include, job content, organizational conditions, and employees' capacities, as well as needs, culture, personal extrajob considerations via perceptions and experience, work performance, and job happiness.

Psychosocial factors encompass components of the job and work environment such as organizational climate, job roles, workplace interpersonal relationships and work design /content (e.g. variety, meaning, scope, repetitiveness, etc.). Psychosocial factors include extraorganizational factors (e.g., household duties) as well as personal characteristics (e.g., personality and attitudes) that might influence the development of stress at work. When it comes to working circumstances that might lead to stress, the terms work organization or 
organizational factors are sometimes used interchangeably with psychosocial factors (Sauter, Murphy, Hurrell, \& Levi, 1998).

\subsection{Leadership Quality (LQ)}

The features, qualities, and actions of the leader are commonly used to determine the $\mathbf{L Q}$. The notion of quality leadership is based on leadership theories and total quality management (TQM) theories, with major goals of improving organizational performance and increasing employee job satisfaction (Puffer \& McCarthy, 1996). An individual personal attributes, talents, and competencies impact the output of quality leadership results at both the supervisory and corporate levels. Leadership quality makes it necessary for quality principles to become the basic frameworks for guiding, empowering and supporting the constant pursuit of excellence within the organizational context. (Feigenbaum, 2007). The leadership style used in organization will determine the $\mathbf{L Q}$ available in the workplace. In the words of EscribaMoreno, Canet-Giner, and Moreno-Luzon (2008), noted that the more participative the leadership style and the more intense the level of decentralization, the more intense the degree of team autonomy and the level of resources required to exercise that power, so the more effective the organization turns.

\subsection{Job Demand (JD)}

The extent to which the working environment provides incentives or components that require some effort is referred to as Job Demand (Jones \& Fletcher, 1996). It refers to components of the job that need continuous effort and as a result, incur some expenditures. Physical, psychological, social, and organizational demands might all be present in the job (Beutell, 2010). Challenge job stressors and hindrance job stressors are the two types of JD. Role conflict, role overload, and role ambiguity are examples of "hindrance job stresses," which are unpleasant, undesirable, and excessive factors in the work that obstruct an individual's capacity to achieve job goals. These characteristics are seen to be undesirable features of job expectations (Judge, Erez, \& Bono, 1998). "Challenge job stressors," are stressors that have the potential to encourage an employee's personal and professional growth, and may contain aspects such as heavy workload, time pressure, and many duties. The features of challenging job stresses are seen as positive stressors because of their unique ability to reward particular employees (Cohen-Charash \& Spector, 2001). JD may be extended to emotional JDs. Van Emmerik and Peeters (2009) sees job demand as the affective component of work and the amount to which an individual is exposed to emotionally unpleasant events as a result of their work or task. Physical JD may also be defined as the amount of physical effort necessary to complete a task in an organizational environment.

\subsection{Work-Family Conflict (WFC)}

Greenhaus and Beutell (1985) defined WFC as a sort of inter-role conflict in which role restrictions from the work and family domains are mutually contradictory or incompatible. 
Extensive involvement in family activities makes participation in work activities more challenging (Van Steenbergen \& Ellemers, 2009; Kalliath, Hughes \& Newcombe, 2012). In other words, employees have several duties that require time, energy, and other resources that may be better spent on other elements of their lives. Consumption of these resources causes disproportionate resource allocation to one position over another, generating uncertainty or conflict (Rothbard, 2001; Greenhaus \& Powell, 2003). WFC may be classified into three types which are time-based, strain-related, and behaviour-based (Greenhaus \& Beutell, 1985). Timebased conflict occurs when an individual's commitment to one role interferes with their ability to engage in another. Work and family are the two most significant components of most people's lives, and they are interconnected to keep individuals alive and psychologically well. The interference between work duties and family responsibilities will continuously persist except there are some element of flexibility in the work responsivities. Employees are ever seeking for means to provide the very best for their families while also willing to deliver optimal performance in their organization. In an attempt to meet these quests of providing the best for their family and also achieving optimal performance, WFC do occur.

\subsection{Concept Employee Performance}

Employee performance refers to the accomplishment of employee set target in terms of the quality and quantity of work delivered by the individual employee in the organization. performance is a critical indication that is frequently linked to an organization's result and success. Employee performance is a way to evaluate an employee's effort at work, and it's a big part of organizational psychology research (Yahaya, Yahaya, Talib Bon, Ismail, \& Chui Ing, 2011). Employee performance refers to how well an employee carries out the organization's goal in the workplace (Cascio, 2006). In other words, employee performance refers to the extent to which individual employees fulfill the organization's overall goals and objectives. The degree of achievement in a certain activity or mission that comes within the parameters of organizational performance objectives determines an employee's obligation (Cascio, 2006). Employee performance according to Ramya (2016) is defined by the activities and behaviours that individual exhibit in the context of the business or workplace. This means that employee performance is a measure of an individual's contribution to an organization's overall objectives or goals over time. Employee performance may be divided into four categories which according to Scullen (2000) include i) general performance, ii) human performance, iii) technical performance, and iv) administrative performance. To Rubina, Amjad, and Khan (2008), employee performance is determined by three factors: skill, effort, and the type of work environment. Employees' skills include their knowledge, talents, and competences; effort refers to how motivated an individual worker is to complete the job; and the nature of work environment refers to how accommodating these factors are in aiding the individuals' performance.

\subsection{Employee Health}

Employee health is defined as workers' well-being as a result of various variables that could impact on job performance (Mattke, Balakrishman, Bergamo, \& Newberry, 2007). Employee health has to do with the mental and physical wellbeing of the workers. The health of the 
employees influences their psychological state which thus impact on their outcome in the organization. Employee health can be viewed in terms of biological viewpoint or the humanistic perspective (Medin \& Alexandersson, 2000). The biological viewpoint begins with disease or sickness in mind, and health is defined as the absence of disease (Boorse, 1977). The humanistic viewpoint sees health as more than just the absence of sickness (Naidoo \& Wills, 2000; Medin \& Alexandersson, 2000). Employee health, in the humanistic sense, extends beyond physical factors to include social, mental, and emotional factors that all contribute to individual employee well-being. Furthermore, to Pfeffer (2010), various studies have suggested that employee health is a specific significant indication of individual or human sustainability, and that it is, of course, an important component of workplace research. Employee health are vital in organization because it influences their performance and total organizational sustainability.

\subsection{Leadership Quality and Employee Performance}

An examination of transactional, transformational, and passive leadership styles, as well as their relationships with quality management methods in Saudi Arabian public hospitals was examined by Alharbi and Yusoff (2012). The results revealed that transformational leadership has a greater beneficial impact on quality management practices and organizational performance, but passive leadership has a negative impact on quality management practices. Laohavichien, Fredendall, and Cantrell (2009) investigated the influence of transactional and transformational leadership on an organization's quality improvement. To the findings, the transformational leadership style had an impact on the infrastructure and key features of quality management, but the transactional leadership style had no impact on the organization's operations. Hirtz, Murray, and Riordan (2007) also said that the leadership style and quality used has an effect on policy implementation and control, as well as employee performance. Similarly, Laskhman (2006) stated that various quality studies have confirmed that the key to good management begins with the organization's senior leadership. As a result, the QOL has a favourable relationship with employee performance. Similarly, in a study of leadership and employee performance of 599 county employees in Kenya using analysis of variance (ANOVA), NawoseIng'ollan \& Rousse (2017) found that the QOL style influences employee performance, with affiliative leadership accounting for $49.5 \%$ and authoritative leadership accounting for $52.2 \%$ of employee performance. The authors came to the conclusion that the quality of the two leadership styles has an impact on the behaviour of county government employees in Turkana County. Similarly, 115 people responded to a survey about the impact of leadership on employee performance among Malaysian jewelry artists. Only the quality of supportive and transformative leadership behaviour has a favorable and substantial impact on employee performance at work, to the findings. As a result of the foregoing, we hypothesize that;

$\mathrm{HO}_{1}$ : There is no significant relationship between leadership quality and employee performance.

\subsection{Leadership Quality and Employee Health}


Alloubani and Almatar (2014) performed an integrated evaluation of impact of leadership styles on quality of services in healthcare. Findings showed that transformational leadership attributes and behaviours were positively associated with organizational outcomes such as teamwork success, effectiveness, staff satisfaction, commitment and extra effort, and more using keyword phrases such as nursing leadership, health leader, leadership roles, health policy, and other related phrases. Furthermore, transformational leadership techniques have been shown to improve followers' work-related values and influence followers' or workers' health state. To Hartley, Martin, and Benington (2008), leadership is a critical component in improving worker health and organizational productivity, as well as employee capacity. Chen (2004) discovered that leadership quality has a good job with employee emotional state, which leads to job satisfaction or discontent. This means that employees develop various health conditions as a result of a leader's contribution in the workplace, such as rest, stress, burnout, and mental problems. Janssen (2004) looked at the leadership qualities of 116 Iowa hospital CEOs and the factors that determine their leadership style." Employees' additional effort, perceived effectiveness, and job satisfaction levels were all substantially connected with transformational leadership, to the findings. Furthermore, the study discovered that while there was no significant association between age, years of experience, setting, or duration of training and leadership style, leadership did have an impact on employee health. Kleinman (2004) discovered a link between nursing administration leadership behaviours and employee job satisfaction and retention, indicating that leadership attitudes have an impact on employees' emotions and willingness to stay with a company. Similarly, Loke (2001) discovered that leadership behaviours explained $29 \%$ of employee satisfaction in the workplace, which is a big part of their health state. "Nurse leaders' perspectives of what constitutes good leadership in today's acute inpatient setting," to Upenieks (2003). To the findings, $83 \%$ of nurse leaders believe that having access to authority, opportunity, knowledge, and resources produces a favorable work environment and climate that leads to healthy sentiments and excellent work conditions among staff. There is no conclusive data about the relationship between leadership quality and employee health; hence, the second hypothesis.;

\section{$\mathrm{HO}_{2}$ : There is no significant relationship between leadership quality and employee health.}

\subsection{Job Demand (JD) and Employee Performance}

When job expectations are not adequately managed, they can cause job stress, which has a substantial influence on the organization's and individuals' performance, as well as their health (Mimura \& Griffiths, 2003). JD can have negative implications, especially when it necessitates extra effort to meet work objectives (Peeters, Montgomery, Bakker, \& Schaufeli, 2005). Physical JD, to Nahrgang, Morgeson, and Hofmann (2011), refers to stresses related with the physical surroundings, such as humidity, illumination, temperature, and noise. Workers, particularly health workers, could scarcely get any job done without electric illumination, hence these features have proven a good association with employee performance. Physical JDs harm health professionals, particularly nurses, to Bakker, Demerouti, and Euwema (2005). Nurses also tend to work in uncomfortable positions, stand for extended periods of time, and handle medical equipment that might be heavy, causing greater harm to their energy in the delivery of superior medical services, to the research. This means that JD, particularly physical 
demands, has a beneficial impact on employee performance. To research, nursing may be a physically hard, stressful, and demanding job with a strong focus on job performance (McFadzean \& McFadzean, 2005). Many research, including applied occupational studies, have identified the influence of JDs on psychological and physical strain as well as job performance (Hart \& Cooper, 2001). In addition, Dwyer and Fox (2004) examined the link between demands and performance and found that the two variables had little or no relationship. That is, the link between JD and performance is not consistent over time and is affected by other factors such as company culture, leadership quality, and family conflict. Because there is no agreement on how JD predicts employee performance, the third hypothesis is proposed;

\section{$\mathrm{HO}_{3}$ : There is no significant relationship between job demand and employee performance}

\subsection{Job Demand and Employee Health}

One of the most difficult tasks for workers is to manage the conflict between the interests of many stakeholders and JDs (Boyne, 2002). In other words, JD refers to the tensions that employees confront at work, and how they are managed has a good or bad impact on workers' health. External actors with extensive influence over resources and decision-making in the public sector lead to increased JD; for example, political actors can have an impact on public organizations, their workforce, and JD, which in turn affects work feelings and health in the short and long term (Pandey \& Wright, 2006). Similarly, Ekholm (2012) observed that employees are frequently in a confused emotional state of mind or a conflict of loyalties as a result of stakeholders' dynamic demands and expectations. This means that complicated JDs have an impact on individual workers' emotional well-being, which is a major health factor that impacts employee stability when handling a job or task. Wikström and Dellve (2009) found that job pressures contribute to emotional stability, which makes it harder to keep up with administrative tasks within the organizational structure. Furthermore, Schat and Kelloway (2005) recognized conflict, notably between superiors and subordinates as well as between coworkers, as another facet of JD that has been stressed in the literature for a long time. Such confrontations, to the authors, may be difficult for managers to deal with and might pose a risk to employees' health and stress levels. To the same study, workplace conflict at both the top and bottom levels has a good impact on individual workers' stress levels, which in turn affects their health. In a survey of managers in the Swedish public sector conducted by Wikström and Dellve (2009), supervisors reported that obstacles in dealing with workers were on the rise, as employees' health-related problems might stem from causes other than disputes. Apart from competing job expectations, Skagert, Dellve, Eklöf, Pousette, and Ahlborg (2008) observed that challenges such as subordinate trust and dealing with subordinates who are unwilling to execute their role have been proposed as causing stress and affecting employee health directly or indirectly. To elucidate how JD affects employee health, the fourth hypothesis was proposed;

$\mathrm{HO}_{4}$ : There is no significant relationship between job demand and employee health.

\subsection{Work- Family Conflict and Employee Performance}


Hoobler, $\mathrm{Hu}$, and Wilson (2010) found that both work-life conflict (WFC) and family-life conflict (FWC) are adversely associated not just to managers' judgments of their employees' job performance, but also to workers' self-reports of their performance. WFC does not have a substantial association with job performance, to Karatepe and Bekteshi (2008). Karetepe and Kilic (2009) discovered, in a later study, that there is a positive association between WFC and employee job performance in organizational contexts. This finding is comparable to that of Van Dyne, Jehn, and Cummings (2002), who discovered that stress caused employees to focus more on their work, resulting in higher sales performance and increased organizational efficiency. Furthermore, while Karatepe and Uludag (2008) found that both directions of conflict (WFC and FWC) have a significant positive relationship with employees' intentions to quit their current jobs, Karatepe, Kilic, and Isiksel (2008) and Balmforth and Gardner (2006) found that only FWC is positively related to employees' intentions to quit their current jobs. Furthermore, research on the same topic by Post, DiTomaso, Farris, and Cordero (2009) found that FWC does actually raise workers' intentions to quit the company, albeit work discontent plays a key role in their connection. Ajala (2017) conducted a survey of 300 public hospital and local government employees in Ekiti, and the data was analyzed using mean, standard deviation, and Pearson Product Moment Correlation Coefficient. Findings demonstrated that work-family-conflict was more prominent in working moms than family-work-conflict; hence, there was a positive significant association between work-family-conflict, family-work conflict, and working mothers' task performance at work. Furthermore, Rose, Hunt, and Ayers (2007) recognized that work-life conflict has a significant impact on organizational performance outcomes because it affects employees' experiences of decreased job employee, increased employee intention to quit and absenteeism, hampered performance, and increased job stress. As a result of the foregoing, the study postulated that;

$\mathrm{HO}_{5}$ : There is no significant relationship between work-family conflict and employee performance

\subsection{Work-family Conflict and Employee Health}

Grice, McGovern, Alexander, Ukestad, and Hellerstedt (2011) performed study with the hypothesis that the WFC and FWC are linked to the emotional and physical health of postpartum women in Minnesota. The results showed that both sides of WFC are adversely related to mental health, but there was no apparent link between job spillover and employee physical health. Several additional research looked at the same factors, and the bulk of the findings suggested that WFC is linked to bad health (Greenhaus, Allen \& Spector, 2006). Similarly, Lallukka, Chandola, Roos, Cable, Sekine, Kagamimori, Tatsuse, Marmot, and Lahelma (2010) conducted a study on "the associations of WFC and unhealthy behaviours among British, Finnish, and Japanese employees," with the findings revealing that WFC is associated with negative or unhealthy work habits of females in Finland, such as smoking, and WFC was associated with unhealthy behaviours like drinking among British females. These findings revealed that WFC had a substantial favorable link with both Finnish and British women. Furthermore, many researches on WFC have shown both divergent and convergent results. WFC, to Greenhaus, Allen, and Spector (2006) has a significant impact on negative feelings such as despair, anxiety, aversion, resentment, and even fury, as well as heightened 
levels of psychological stress (Kalliath, Hughes \& Newcombe, 2012). Employees who are facing WFC feel awful when they don't meet up with both work and family obligations, to Lazarus and Cohen-Charash (2001). This has an impact on their health, particularly in the emotional and mental aspects of their lives. WFC, to Judge, Ilies, and Scott (2006), has a more negative influence on IIIIIII employee sentiments, which can lead to hatred toward the job and coworkers. This means that employees who are unable to satisfy role expectations from both family and employee may act badly toward those around them as a result of their poor health. The sixth hypothesis, based on the preceding reasoning, was expressed as follows;

\section{$\mathrm{HO}_{6}$ : There is no significant relationship between work-family conflict and employee health}

\section{Methodology}

The study used a survey design technique, which allowed for the collection of data from the study's target population within a set time frame. Employees of 10 public hospitals in Rivers State are the population of the study. The study used a simple random sample technique in which ten employees from each hospital were given a copy of the questionnaire, totaling 100 copies. As adopted from the study, the independent variables (psychological work factor) were operationalized in terms of leadership quality, job demand, and work-family conflict (Karasek \& Theorell, 1990; Siegrist, 1996; and Ekholm, 2012). Five questions were used to assess workfamily conflict (e.g. I have to make plans for my family due to work-related duties, work keeps me far from family more than I prefer, my home duties are sluggish because of task at workplace). In addition, five items were utilized to assess leadership quality (e.g. my immediate super makes sure that the members of staff have good development opportunities, immediate supervisor my immediate supervisor is willing to listen to my problems, my immediate supervisor display high leadership quality in my organization). Then, using five items, job demand was assessed (e.g. I hardly have time to complete all my work tasks, I work at a high pace throughout the day, my work is emotionally demanding). The dependent variables (employee performance and employee health) were also modified from Ramya (2016) and Pfeffer (2016). (2010). Five items were used to assess employee performance (e.g. family issues affect my rate of task completion, leadership support relates to the extent I achieve the objective of the day). Employee health was assessed using a five items (e.g. my boss gives me headache each day, my daily task affects my emotions). All of the items were assessed on a four-point Likert scale, with 1-strongly disagree, 2-disagree, 3-agree, and 4-strongly agree being the highest scores. Statistical Package for Social Sciences (SPSS) version 21.0 was used to examine the association between the variables using the Spearman rank correlation coefficient.

\section{Results}

A total of 100 copies of the questionnaire were given and returned to the responder, with $100 \%$ of the copies being returned. Only 97 (97\%) of the total returned copies were well completed and considered valid for analysis, while $3(3 \%)$ were not. To the descriptive data, $67(69.1 \%)$ of the respondents were female, while $30(30.9 \%)$ of the respondents were male. This means that majority of the employees in the public hospitals in Rivers State are female. The 
hypotheses were tested at a 95\% confidence interval, assuming a $0.05 \%$ level of significance, with the decision rule set at sig $<0.05$ for acceptance of alternative hypotheses and rejection of null hypotheses if otherwise.

Table 1: Correlation of leadership quality and employee performance

\section{Correlations}

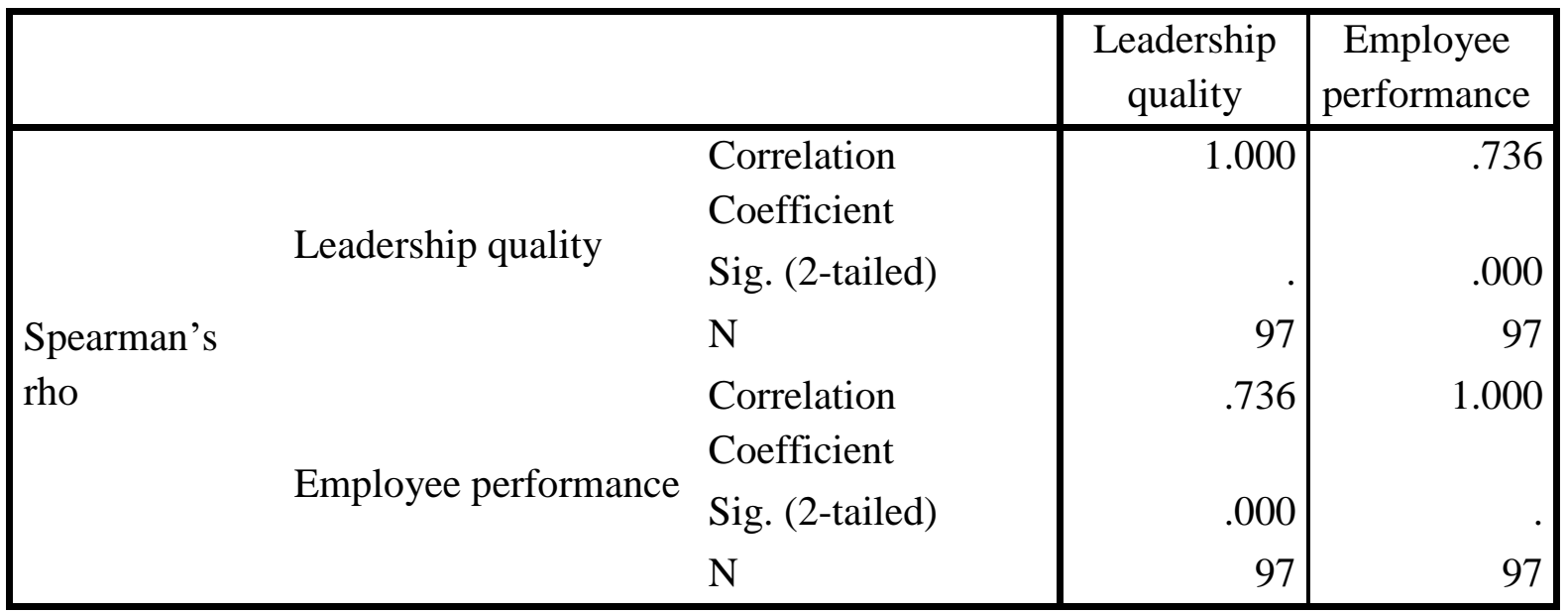

**. Correlation is significant at the 0.05 level (2-tailed).

With a Sig. of $0.000<0.05$ level of significance and a rho value of 0.736 , the bivariate analysis in table 1 revealed that there is a significant association between leadership quality and employee performance. As a result, the null hypothesis was rejected and the alternative hypothesis, which indicated that there is a strong association between leadership quality and employee performance of public hospitals in Rivers state, was accepted.

Table 2: Correlation of leadership quality and employee health

\section{Correlations}

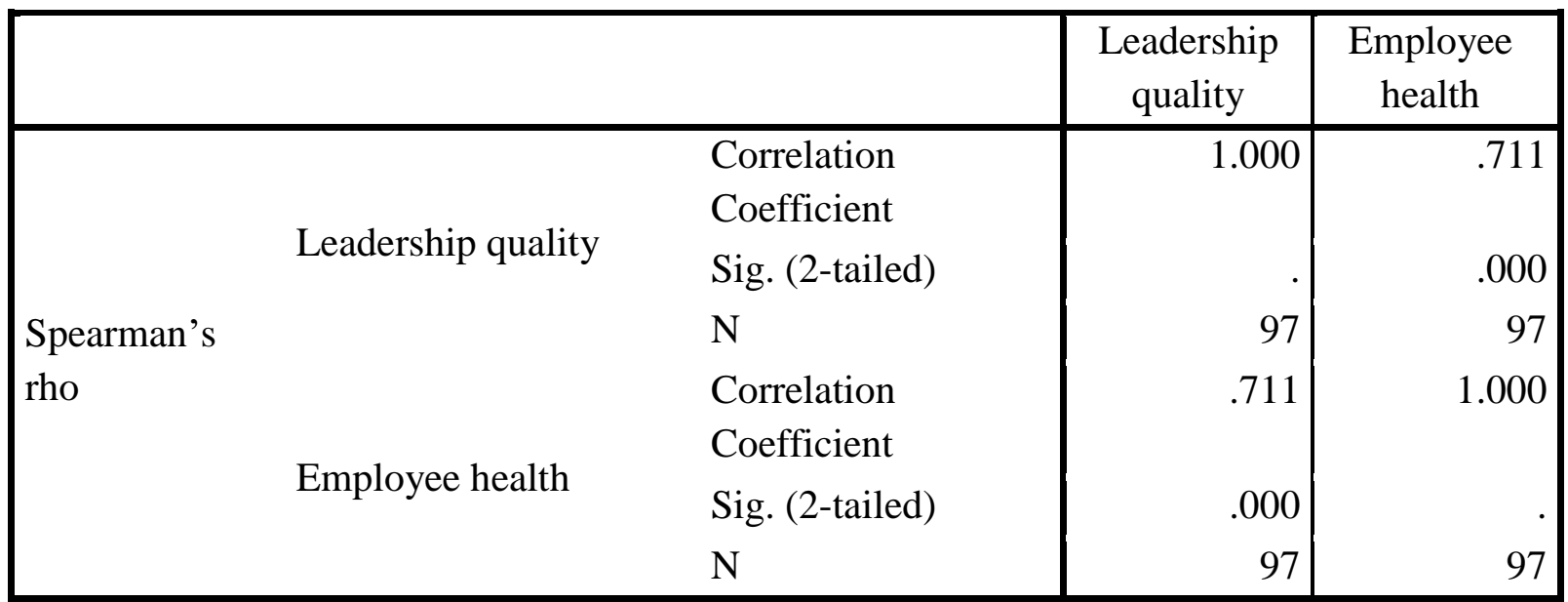

**. Correlation is significant at the 0.05 level (2-tailed).

With a Sig. of $0.000<0.05$ level of significance and a rho value of 0.711 , the bivariate analysis in table 2 revealed that there is a significant link between leadership quality and employee health. As a result, the null hypothesis was rejected, and the alternative hypothesis, stating that there is a substantial association between leadership quality and employee health in public 
hospitals in Rivers state, was accepted.

Table 3: Correlation of work-family conflict and employee performance

\section{Correlations}

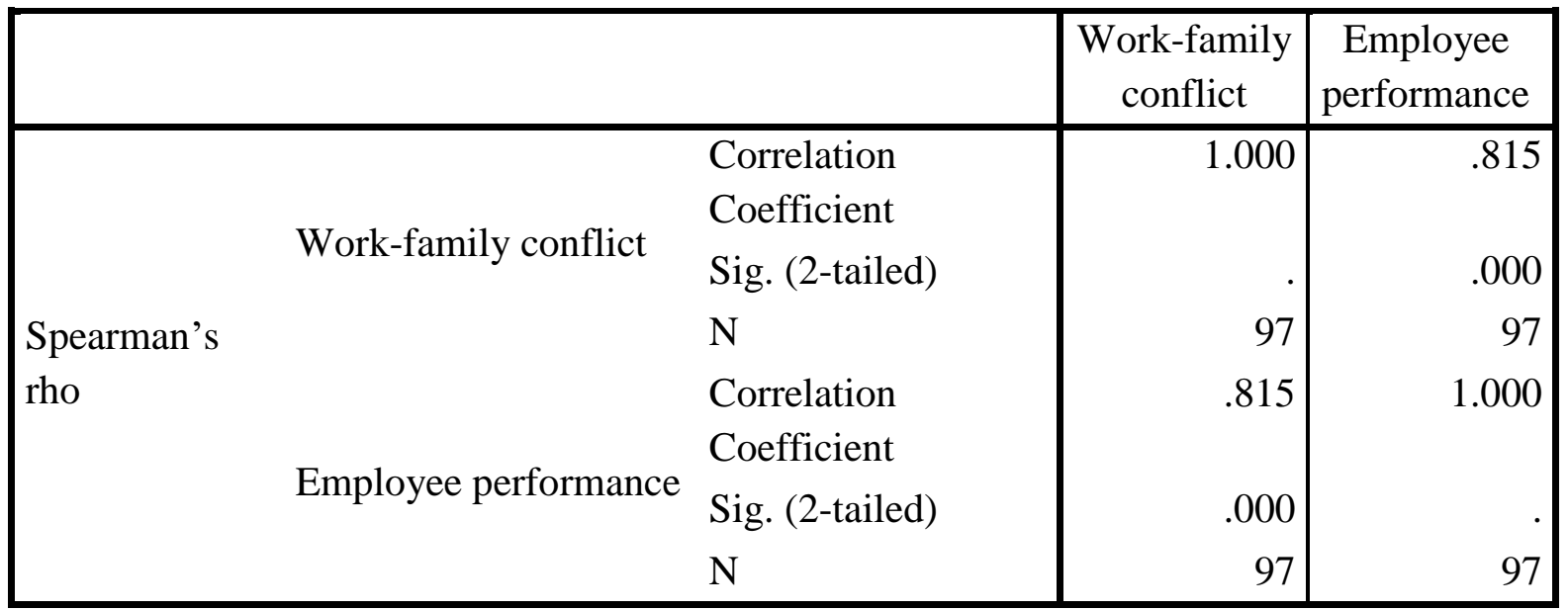

**. Correlation is significant at the 0.05 level (2-tailed).

With a Sig. of $0.000<0.05$ level of significance and a rho value of 0.815 , the bivariate analysis in table 3 revealed that there is a significant link between work-family conflict and employee performance. As a result, the null hypothesis was rejected, and the alternative hypothesis, stating that there is a substantial association between work-family conflict and public hospital employee performance in Rivers state, was accepted.

Table 4: Correlation of work-family conflict and employee health

\section{Correlations}

\begin{tabular}{|lll|r|r|}
\hline & & $\begin{array}{c}\text { Work-family } \\
\text { conflict }\end{array}$ & $\begin{array}{c}\text { Employee } \\
\text { health }\end{array}$ \\
\hline & & Correlation & 1.000 & .812 \\
& Work-family conflict & Coefficient & & \\
& & Sig. (2-tailed) &. & .000 \\
Spearman's & & $\mathrm{N}$ & 97 & 97 \\
rho & & Correlation & .812 & 1.000 \\
& & Coefficient & .000 & \\
& & Sig. (2-tailed) & 97 & 97 \\
\hline
\end{tabular}

**. Correlation is significant at the 0.05 level (2-tailed).

With a Sig. of $0.000<0.05$ level of significance and a rho value of 0.812 , the bivariate analysis in table 4 revealed that there is a significant link between work-family conflict and employee health. As a result, the null hypothesis was rejected, and the alternative hypothesis, stating that there is a strong link between work-family conflict and employee health in public hospitals in Rivers state, was accepted. 
Table 5: Correlation of job demand and employee performance

\section{Correlations}

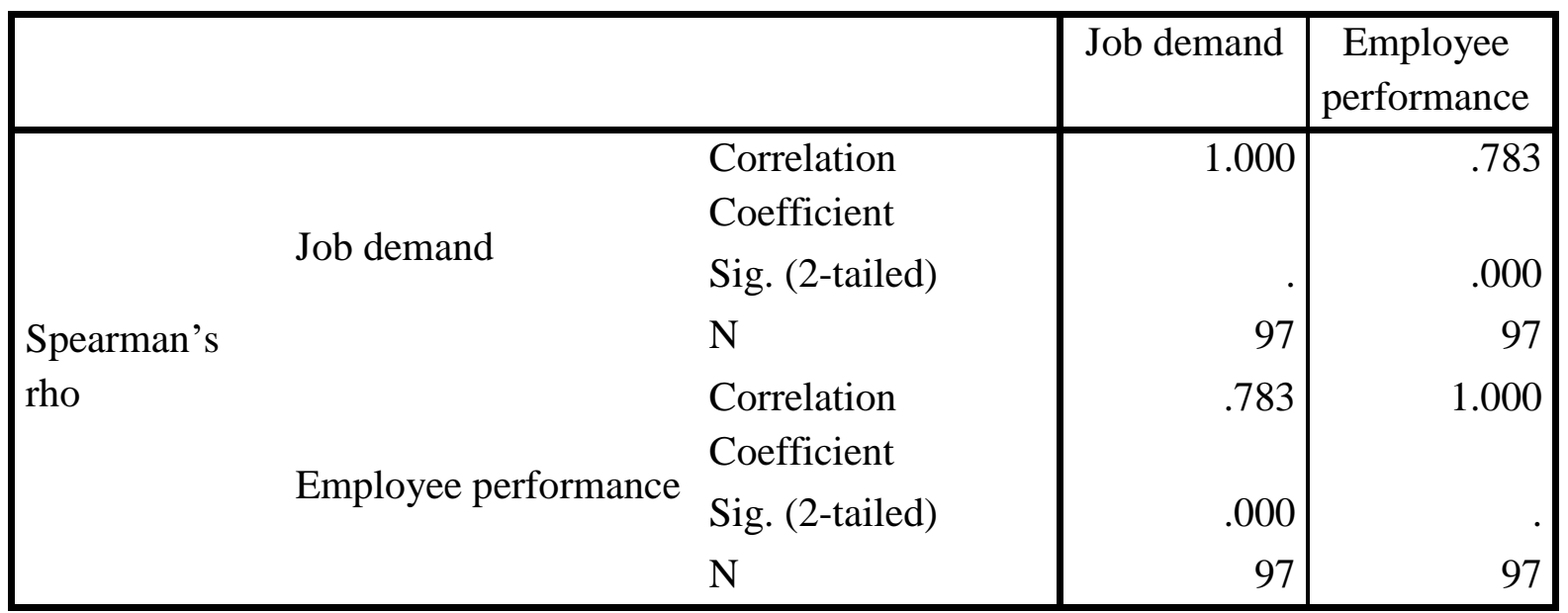

**. Correlation is significant at the 0.05 level (2-tailed).

With a Sig. of $0.000<0.05$ level of significance and a rho value of 0.783 , the bivariate analysis in table 5 revealed that there is a significant link between job demand and employee performance. As a result, the null hypothesis was rejected, and the alternative hypothesis, that there is a substantial link between job demand and employee performance in public hospitals in Rivers state, was accepted.

Table 6: Correlation of job demand and employee health

\section{Correlations}

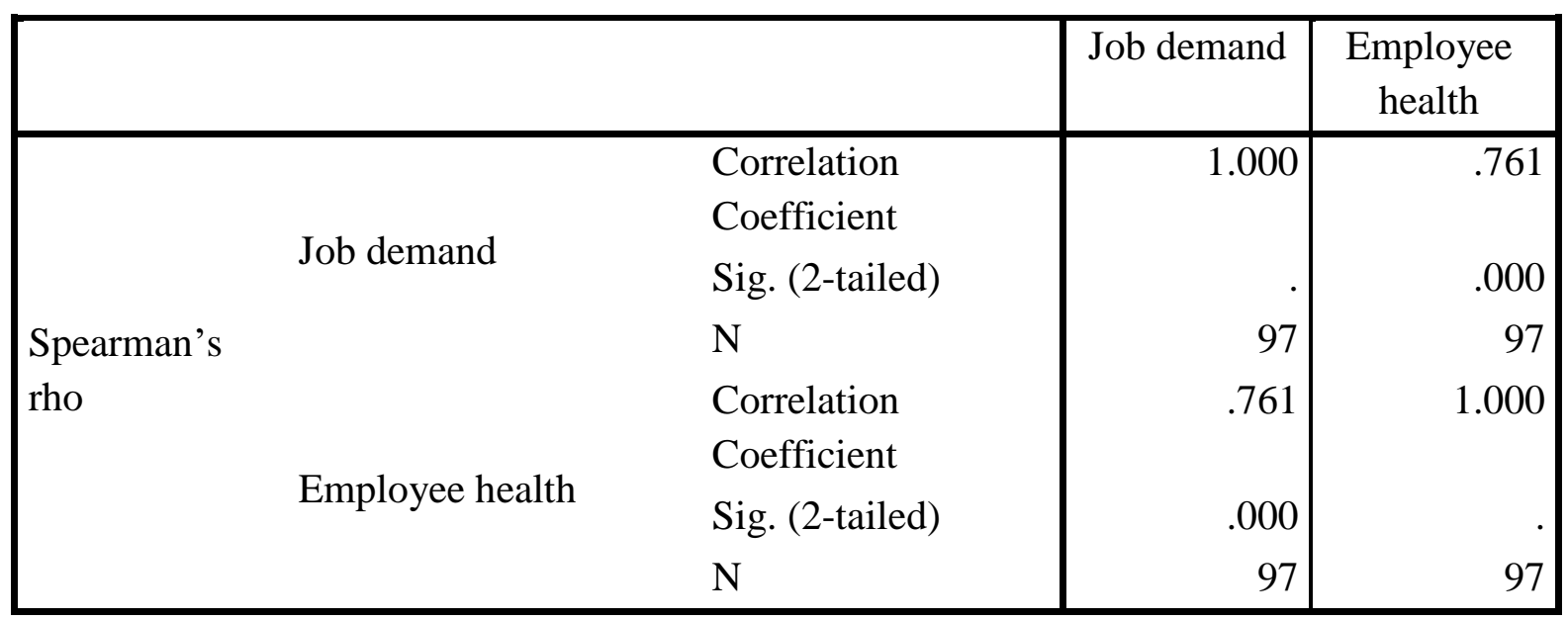

**. Correlation is significant at the 0.05 level (2-tailed).

With a Sig. of $0.000<0.05$ level of significance and a rho value of 0.761 , the bivariate analysis in table 6 revealed that there is a significant link between job demand and employee health. As a result, the null hypothesis was rejected, and the alternative hypothesis, that there is a strong association between job demand and employee health in public hospitals in Rivers state, was accepted.

\section{Discussion of Findings}


The findings found that psychosocial work factor have a positive relationship with employee performance and health, with work-family conflict having the strongest positive correlation with employee health. Based on a P-value less than 0.05 ( $\mathrm{P}$-value $=0.000<0.05)$ and a rho value of $=0.736$, the first hypotheses suggested that leadership quality has a positive linear noticeable association with employee performance. Thus, leadership qualities influence the performance of the employees. The findings found that practically every psychosocial work factor had a positive association with employee performance and health, with work-family conflict having the strongest positive correlation with employee health. Furthermore, based on the P-value less than 0.05 (P-value $=0.000<0.05$ ) and rho value of $=0.711$, the second hypotheses revealed that leadership quality has a positive linear notable correlation with employee health, implying that leadership quality and employee health are moving in the same positive direction. Thus, aspects of leadership quality, such as strong growth possibilities, supervisors' readiness to listen to my difficulties, and high leadership quality in my organization, are linked to employee health in a favorable way.

In alignment with the third hypothesis, work-family conflict has a positive linear substantial correlation with employee performance, with a P-value less than 0.05 ( $\mathrm{P}$-value $=0.000<0.05$ ) and rho value of $=0.815$, implying that work-family conflict and employee performance are moving in the same positive direction. This suggest that work family conflict has an impact on the performance of the employees. When the work family conflict is well managed, such will help boost the performance of the workers. Furthermore, based on the P-value less than 0.05 $(\mathrm{P}$-value $=0.000<0.05)$ and rho value of $=0.812$, the fourth hypotheses revealed that workfamily conflict has a positive linear notable correlation with employee health, implying that work-family conflict and employee health are moving in the same positive direction. As a result, elements of work-family conflict, such as making family plans owing to work-related obligations, have a beneficial impact on employee health. Work family conflict impact on the health of the employees. Thus, the health of the employees can be enhanced when there is a proper balance between work and family responsibilities.

Furthermore, based on the P-value less than 0.05 (P-value $=0.000<0.05)$ and rho value of $=$ 0.783 , the fifth hypotheses revealed that job demand has a positive linear notable correlation with employee performance, implying that job demand and employee performance are positively correlated. Performance of the employees are critical and vital to success of the health sector in order to enhance the quality health service delivery of the organization. Hence, addressing the issue of job demand will help enhance the performance of the workforce. Finally, based on the P-value less than 0.05 (P-value $=0.000<0.05)$ and rho value of $=0.761$, the result of the sixth hypotheses revealed that job demand has a positive linear notable correlation with employee health, implying that job demand and employee health are correlated positively to a high extent. When the demand of the job is high, such could impose stress on the employees which could thus impact on their health. Work that is emotionally demanding all have an impact on employee health. As a result, the positive relationship between psychosocial work factors, employee performance, and employee health has been found to be consistent with previous research, such as Okeafor and Alamina (2018), who used a risk assessment matrix in a survey of medical staff to conduct a "qualitative study on psychosocial hazards among health care workers in a tertiary health facility in South-South Nigeria." Poor 
interpersonal relationships, abuse from patient family, and boredom are among the psychological factors influencing workers in their employment, to the findings of the current study. Moreover, numerous additional research have understudied psychosocial factors, and the bulk of the data imply that work-family conflict is linked to bad health (Greenhaus, Allen \& Spector, 2006). research like Ukestad and Hellerstedt (2011), who used the WFC and FWC methods, discovered that work-family conflict is inversely related to mental health, implying that some psychosocial characteristics aren't always linked to employee performance and work circumstances. Other research, such as Ekholm (2012), Karatepe \& Uludag (2008), Rose, Hunt, and Ayers (2007), are in agreement with the current study's conclusions. They discovered that psychosocial factors such as difficult job demands, work-family conflict, and family-life problems have an impact on individual employees' emotional well-being, which is an important health component that influences employee stability when doing a job or task. These studies also shown that psychosocial work factors have a significant impact on organizational performance since they affect employees' experiences, emotional sentiments, and level of performance.

\section{Conclusion and Recommendations}

psychosocial work factors have been shown to influence individual work performance and health in a variety of sectors. The majority of research claimed that psychosocial work factors had an inverse association with employee performance, suggesting that the variables have a negative link. Psychosocial work factors mostly influence employee performance and health. To the findings of this study, there is a favourable association between psychosocial work factors and employee health, and performance. As a result, the current research shows that psychosocial work factors have a favourable association with employees' performance and health in the public hospitals. As a result of the findings and conclusions, the following recommendations are made:

i. The management of the public hospitals should display a quality leadership style as such will help boost the workers performance and health conditions.

ii. Conditions that promotes employee health risks should be eliminated among public hospital employees, as this will assist to improve their health and performance.

iii. Employees' jobs at public hospitals should be well-planned in order to prevent excessive job demand, which would improve job performance.

iv. Work-family conflict has the strongest link with performance, to research, thus public hospitals that want to improve their employees' performance should guarantee that their employees' family conflict is appropriately managed to avoid it colliding with work responsibilities.

v. Management should guarantee that a more accommodating leadership style is developed in order to improve employee-employer connections, which will improve performance and health.

vi. Employees should be allowed to voice their concerns about their health and workrelated difficulties as this will allow the management to make the required adjustments 
and thus improve improved performance and health of the employees.

\section{Research Limitations and Directions for Future Studies}

The major limitation in tis study was the sample size of the study which was drawn from the public hospitals in Rivers State. The cross-sectional survey employed was another form of limitation because it only captures respondent's opinion at a given period and lack the ability to capture the variation of respondent opinion over a different period. The study examined employee performance and health directly without examining their measures. Hence, future study should utilize a longitudinal survey design and the measures of employee performance and health should be critically examined in future studies.

\section{References}

1) Ajala, E.M (2017). Work-family-conflict and family-work-conflict as correlates of job performance among working mothers: implications for industrial social workers. African Journal of Social Work, 7(1), 52-62.

2) Akhigbe, E. A., \& Eketu, C. A. (2021). Psychosocial work factor and withdrawal behaviour among medical doctors in Teaching hospitals in south-south, Nigeria. International Academy Journal of Management, Marketing and Entrepreneurial Studies, 8(3), 78-92.

3) Sharma, J., Dhar, R. L., \& Tyagi, A (2016). Stress as a mediator between work-family conflict and psychological health among the nursing staff: Moderating role of emotional intelligence. Applied Nursing Research, 30, 268-275.

4) Alharbi, M., \& Yusoff, R. Z. (2012). Leadership styles, and their relationship with quality management pratices in public hospitals in Saudi Arabia. International Journal of Economics and Management Sciences, 5(10), 59-67.

5) Alloubani, R.N. A \& Almatar, M (2014). Review: effects of leadership styles on quality of services in healthcare. European Scientific Journal, 10, 18, 118-121

6) Bakker, A.B., Demerouti, E., \&., Euwema, M.C (2005). Job resources buffer the impact of job demands on burnout. Journal of Occupationaal Health Psychology, 10, 170-180. PMID: 15826226

7) Balmforth, K., \& Gardner, D (2006). Conflict and facilitation between work and family: Realizing the outcomes for organizations. New Zealand Journal of Psychology, 35(2), 69-76

8) Baranuaskiene, I., Dirzyte, A., \& Valaikiene, A (2010). Relation of Psychosocial Job Factors to Job Satisfaction, Quality of Life, Sense of Harmony among Officers of Correlational Institutions. Socialiniai tyrimai / Social Research, 1 (18), 29-39

9) Bass, B. M., \& Riggio, R. E (2006). Transformational leadership. Mahwah, NJ: Lawrence Erlbaum.

10) Beutell, N.J (2010). Work schedule, work schedule control and satisfaction in relation to work-family conflict, work-family synergy, and domain satisfaction. Career Development International, 15(5), 501-518.

11) Boorse, C (1977). Health as a theoretical concept. Philosophy of Science, 44, 542-573. 
12) Boyne, G (2002). Public and private management: What's the difference? Journal of Management Studies, 39(1), 97-122

13) Cascio, W. F (2006). Managing Human Resources: Productivity, Quality of Life, Profits. McGraw-Hill Irwin.

14) Ceballos-Vásquez, P., Rolo-González, G., Hérnandez-Fernaud, E., Díaz-Cabrera, D., Paravic-Klijn, T., Burgos-Moreno, M (2015). Psychosocial factors and mental work load: a reality perceived by nurses in intensive care units. Rev. Latino-Am. Enfermagem, 23(2), 22.

15) Chen, L.Y. (2004). An examination of the relationships among leadership behaviours, knowledge sharing, and marketing effectiveness in professional service firms that have been engaged in strategic alliances. Unpublished doctoral dissertation, Nova Southeastern University

16) Cohen-Charash, Y \& Spector, P.E (2001). The role of justice in organizations: A metaanalysis. Organizational Behaviour and Human Decision Processes, 86(2), 278-321.

17) de Jonge, J., Bosma, H., Peter, R., \& Siegrist, J (2000). Job strain, effortreward imbalance and employee well-being: a large-scale cross-sectional study. Social Science \& Medicine, 50, 1317-1327.

18) Diab, S.M \& Ajlouni, M.T (2015). The influence of training on employee's performance, organizational commitment, and quality of medical services at Jordanian private hospitals. International Journal of Business and Management, 10 (2), 117-127

19) Dwyer, D. J \& Fox, M. L (2004). The relationship among work stressors and key performance indicators: A test of the moderating effects of control and customer service training in call centers. Manuscript submitted for publication

20) Eby, L.T., Casper, W. J.,wood A., Bordeaux, C., \& Brinley, A (2005). Work and family research in IO/OB: Content analysis and review of the literature (1980-2002). Journal of Vocational Behaviour, 66, 124-197.

21) Ekholm, B (2012). Middle managers in elderly care under demands and expectations. Leadership in Health Services, 25(3), 203-215.

22) Escriba-Moreno, M. A., Canet-Giner, M.T., \& Moreno-Luzon, M (2008). TQM and teamwork effectiveness: the intermediate role of organizational design. Quality Management Journal, 15 (3), 41-59

23) Feigenbaum, A.V (2007). The international growth of quality. Quality Progress, 40 (2), $36-40$

24) Fernandes, C \& PereiraI, A (2016). Exposure to psychosocial risk factors in the context of work: a systematic review. Rev Saude Publica, 50, 24.

25) Greenhaus, J. H \& Powell, G. N (2003). When work and family collide: deciding between competing role demands. Organizational Behaviour and Human Decision Processes, 90 (2), 291-303.

26) Greenhaus, J. H \& Powell, G. N (2006). When work and family are allies: A theory of work-family enrichment. Academy of Management Review, 31(1), 72-92.

27) Greenhaus, J.H \& Beutell, N.J (1985). Sources of conflict between work and family roles. Academy of Management Review, 10, 76-88. 
28) Grice, M. M., McGovern, P. M., Alexander, B. H., Ukestad, L., \& Hellerstedt, W (2011). Balancing work and family after childbirth: A longitudinal analysis. Women's Health Issues, 21(1), 19-27.

29) Hart, P. M \& Cooper, C. L (2001). Occupational stress: Toward a more integrated framework. In A. N. Anderson, D. S. Ones, H. K. Sinangil, \& C. Viswesvaran (Eds.), Handbook of industrial, work and organizational psychology: 2. Organisational psychology (pp. 93-114). London: Sage.

30) Hartley, J., Martin, J., \& Benington, J (2008). As a report, and in press as a book) Leadership in healthcare: A review of the literature for healthcare professionals, managers and researchers.

31) Hermina, U. N., \& Yosepha, S. Y. (2019). The model of employee performance. International Review of Management and Marketing, 9(3), 69-73.

32) Hirtz, P. D., Murray, S. L., \& Riordan, C. A (2007). The effects of leadership on quality. Engeneering Management Journal, 19(1), 22-27.

33) Hoobler, J. M., Hu, J., \& Wilson, M (2010). Do workers who experience conflict between the work and family domains hit a "glass ceiling"?: A meta-analytic examination. Journal of Vocational Behaviour, 77, 481-494.

34) Ibrahim, M. A., Aziz, A. A., Suhaili, N. A., Daud, A. Z., Naing, L., \& Rahman, H. A. (2019). A study into psychosocial work stressors and health care productivity. International Journal of Occupational and Environmental Medicine, 10, 185-193.

35) Johansson, G., Sandahl, C., \& Hasson, D (2013). Role stress among first-line managers and registered nurses - A comparative study. Journal of Nursing Management, 21, 449458

36) Jones, F., \& Fletcher, B.C (1996). Job control and health. In M. J. Schabracq, J. A. M. Winnubst \& C. L. Cooper (Eds.), Handbook of work and health psychology, 33-50. Chichester: Wiley \& Sons

37) Judge, T. A., Ilies, R., \& Scott, B. A. (2006). Work-family conflict and emotions: effects at work and at home. Personal Psychology, 59. 77-814

38) Judge, T.A., Erez, A \& Bono, J. E (1998). The power of being positive: The relation between positive selfconcept and job performance. Human Performance, 11(2-3), 167187.

39) Kalliath, P., Hughes, M., \& Newcombe, P (2012). When Work and Family are in Conflict: Impact on Psychological Strain Experienced by Social Workers in Australia. Australian Social Work, 65(3), 355-371

40) Karasek, R \& Theorell, T (1990). Healthy Work. Stress, Productivity, and the Reconstruction of Working Life. New York: Basic Books.

41) Karasek, R \& Theorell, T (1990). Healthy work. Stress, productivity and the reconstruction of working life. New York: Basic Book

42) Karatepe, O. M \& Bekteshi, L. (2008). Antecedents and outcomes of work-family facilitation and family-work facilitation among frontline hotel employees. International Journal of Hospitality Management, 27, 517-528.

43) Karatepe, O. M \& Kilic, H (2009). The effects of two directions of conflict and facilitation on frontline employees' job outcomes. The Service Industries Journal, 29(7), 977-993 
44) Karatepe, O. M \& Uludag, O (2008). Affectivity, conflicts in the work-family interface and hotel employee outcomes. International Journal of Hospitality Management, 27, $30-41$.

45) Kennedy, N.A (2018). Assessment of psychosocial hazards among workers at the University of Port Harcourt. Clin Depress, 4, 135.

46) Kivimäki, M, Batty, G.D, Steptoe A, \& Kawachi I, (2018). The Routledge international handbook of psychosocial epidemiology. New York: Routledg.

47) Kleinman, C.S (2004b). Leadership: A key strategy in staff nurse retention. The Journal of Continuing Education in Nursing. 35 (3) 128-132.

48) Kuruppu, C. L., Kavirathne, C. S., \& Karunarathna, N. (2021). The impact of training on employee performance in a selected apparel sector organization in Sri Lanka. Global Journal of Management and Business Research: A Administration and Management, 21(2), 4-12.

49) Lakshman, C (2006). A theory of leadership for quality: Lessons from TQM for leadership theory 1. Total Quality Management \& Business Excellence, 17(1), 41-60

50) Lallukka, T., Chandola, T., Roos, E., Cable, N., Sekine, M., Kagamimori, S., Tatsuse, T., Marmot, M., \& Lahelma, E (2010). Work-family conflicts and health behaviours among British, Finnish and Japanese employees. International Journal of Behavioural Medicine, 17, 134-142.

51) Laohavichien, T., Fredendall, L., \& Cantrell, R. (2009). The effects of transformational and transactional leadership on quality improvement. The Quality Management Journal, 16(2), 7-24.

52) Mattke, S., Balakrishman, A., Bergamo, G., \& Newberry, S.J (2007). A review of methods to measure health-related productivity loss. American Journal of Managing Care, 13 (4), 211-217

53) McFadzean, F \& McFadzean, E (2005). Riding the emotional roller-coaster: A framework for improving nursing morale. Journal of Health Organization. Management, 19, 318-339. DOI: 10.1108/14777260510615378

54) Mimura, C \& Griffiths (2003). The effectiveness of current approaches to workplace stress management in the nursing profession: An evidence based literature review. J. Occup. Environ. Med., 60: 10-15 in Shah et al (2012) Impact of Stress on Employee "s Performance: A Study on Teachers of Private Colleges of Rawalpindi, Asian Journal of Business Management,4(2),101-104

55) Nahrgang, J.D., Morgeson, F.P., \& Hofmann, D.A (2011). Safety at work: A metaanalytic investigation of the link between job demands, job resources, burnout, engagement, and safety outcomes. Journal of Applied Psychology, 96(1), 71-94

56) Naidoo, J \& Wills, J (2000). Health Promotion - Foundations for Practice. Edinburgh: Baillière Tindall.

57) NawoseIng'ollan, D \& Rousse, J (2017). Influence of Leadership Styles on Employees' Performance: A Study of Turkana County, Kenya. International Journal of Business and Social Science, 8 (7), 82-98.

58) Nguyen, M. H., Luan, N. V., \& Khoa, B. T. (2021). Employer attractiveness and employee performance: An Exploratory study. Journal of System and Management Sciences, 11(1), 97-123. 
59) Okeafor, C.O \& Alamina, F.E (2018). A qualitative study on psychosocial hazards among health care workers in a tertiary health facility in South-South Nigeria. Annals of Ibadan Postgraduate Medicine, 16 (1), 24-29

60) Pandey, S \& Wright, B (2006). Connecting the dots in public management: Political environment, organizational goal ambiguity, and the public manager's role ambiguity. Journal of Public Administration Research and Theory, 16(4), 511-532.

61) Peeters, M.C.W., Montgomery, A.J., Bakker, A.B \&., Schaufeli, W.B (2005). Balancing work and home: How job and home demands are related to burnout. International Journal Stress Management, 12, 43-63.

62) Pfeffer, $J$ (2010). Building sustainable organizations: The human factor. Academy of Management Perspectives, 24(1), 34-45.

63) Pleck, J. H (1977). The work-family role system. Social Problems, 24, 417-427.

64) Post, C., DiTomaso, N., Farris, G. F., \& Cordero, R (2009). Work-family conflict and turnover intentions among scientists and engineers working in R\&D. Journal of Business Psychology, 24, 19-32. Rothbard

65) Puffer, S.M \& McCarthy, D.J (1996). A framework for leadership in a TQM context, Journal of Quality Management, 1 (1), 109-130

66) Ramya (2016). The effect of training on employee performance. International Journal of Scientific Research and Modern Education, 1 (1), 698-706

67) Rothbard, N. P (2001). Enriching or depleting? The dynamics of engagement in work and family roles. Administrative Science Quarterly, 46 (4), 655-684

68) Rubina, K Amjad, S., \& Khan, D (2008). Occupational stress and its effect on job performance a case study of medical house officers of district Abbottabad, J Ayub Med Coll Abbottabad, 20(3)

69) Sauter, S.L, Murphy, L.R, Hurrell, J.J, \& Levi, L (1998). Psychosocial and organizational factors. In: Stellman JM, editor. ILO Encyclopedia of Occupational Health and Safety. Geneva: International Labour Office, 34.32-34.33

70) Schat, A \& Kelloway, E. K (2005). Workplace aggression. In J. Barling, E. K. Kelloway, \& M. R. Frone (Eds.), Handbook of work stress, 189-218. Thousand Oaks, CA: Sage.

71) Siegrist J (1996). Advance health effect of high-effort/ low-reward conditions. Journal Occupational Health Psychology, 1(1), 27-41.

72) Skagert, K., Dellve, L., Eklöf, M., Pousette, A., \& Ahlborg G (2008). Leaders' strategies for dealing with own [sic] and their subordinates' stress in public human service organizations. Applied Ergonomics, 39(6), 803-811.

73) Stannack, P (1996). Perspective on employees performance. Management Research News, l19(4/5), 38-40.

74) Upenieks, V (2003). Nurse leaders' perceptions of what comprises successful leadership in today's acute inpatient environment. Nurs Adm Q. 27(2), 14052.

75) Van Emmerik, I.J.H \& Peeters, M.C.W (2009). Crossover specificity of team-level work-family conflict to individual-level work-family conflict. Journal of Managerial Psychology, 24(3), 254-268. 
76) Van Steenbergen, E. F \& Ellemers, N (2009). Is managing the work-family interface worthwhile? Benefits for employee health and performance. Journal of Organizational Behaviour, 30(5), 617-642.

77) Wikström, E \& Dellve, L (2009). Contemporary leadership in healthcare organizations: Fragmented or concurrent leadership. Journal of Health, Organization and Management, 23(4), 411-428.

78) Yahaya, A., Yahaya, N., Talib Bon, A., Ismail, S., \& Chui Ing, T (2011). Stress level and its influencing factors among employees in a plastic manufacturing and the implication towards work performance. Elixir Psychology, 41, 5932-5941. 